\title{
Addiction Needs Neuroscience, Gene Sequencing and Hard Research in Seeking A Cure
}

\author{
Edward Carels* \\ Addiction Medicine Institute, USA
}

Submission: May 11, 2017; Published: May 24, 2017

*Corresponding author: Edward Carels, Founder and CEO of Addiction Medicine Institute, 1024 Bayside Dr. Ste 459, Newport Beach, Ca. 92660, USA, Tel: 949-439-9780; Email: ed222@earthlink.net

\section{Mini Review}

The number of persons afflicted with addiction is growing with an estimated 40 Million diagnosed patients and another 80 million risky substance users one third of America. It is costing America an estimated \$486 Billion annually. Most of the money is going to the judicial system and not treatment or research on better treatments. An estimated 600,000+ die from addiction annually (more than the Vietnam war). It causes 71 other diseases of all kinds. And less than $10 \%$ of people with addiction fail to ever get help for it. In 2010, the United States spent $\$ 43.8$ billion to treat diabetes which affects 25.8 million people, $\$ 86.6$ billion to treat cancer which affects 19.4 million people and an estimated $\$ 107.0$ billion to treat heart conditions which affect 27.0 million people, but only $\$ 28.0$ billion to treat addiction which affects 40.3 million people.

Addiction is still a highly stigmatizing illness and is still perceived by most people even medical professionals as a character defect, moral weakness, or inability to self control. Organized Medicine has done little training of interns and residents about the disease (some improvement in recent years). It's the least likely health category to be asked about in

Table 1: Columbia University Study.

\begin{tabular}{|c|c|c|c|c|c|}
\hline Type of Medication* & $\begin{array}{c}\text { Addiction involving } \\
\text { Alcohol }\end{array}$ & $\begin{array}{c}\text { Addiction involving } \\
\text { Nicotine }\end{array}$ & $\begin{array}{c}\text { Addiction involving } \\
\text { Cocaine }\end{array}$ & $\begin{array}{c}\text { Addiction involving } \\
\text { Opioids }\end{array}$ & $\begin{array}{c}\text { Addiction involving } \\
\text { Marijuana }\end{array}$ \\
\hline $\begin{array}{c}\text { Reduce craving/ withdrawal symptoms } \\
\text { Acamprosate } \\
\text { (Campral) }\end{array}$ & $\mathrm{X}$ & $\mathrm{X}$ & & & \\
\hline $\begin{array}{c}\text { Bupropion (Zyban, } \\
\text { Wellbutrin) }\end{array}$ & & $\mathrm{X}^{*}$ & & & \\
\hline $\begin{array}{c}\text { Nortriptyline } \\
\text { (Pamelor, Aventyl) }\end{array}$ & & $\mathrm{X}^{*}$ & & & \\
\hline $\begin{array}{c}\text { Clonidine (Catapres) } \\
\text { Baclofen (Kemstro, } \\
\text { Lioresal, Gablofen) }\end{array}$ & $\mathrm{X}^{*}$ & $\mathrm{X}^{*}$ & & & \\
\hline Ondansetron (Zofran) & & & & & $\mathrm{X}^{*}$ \\
\hline
\end{tabular}

annual physicals as is the brain itself. How often have you ever had a physician ask you when is the last time you had your head examined. More often that phrase is meant to be either funny or denigrating to whom its directed. Ironically, it's the single most important organ in the body. You can live without most every other organ even your heart (which can be replaced). You cannot get a new brain. That is in part the result of the fact that the brain is the single most important part of your body. And it is also the single most complicated thing in the entire universe as it has more connections in its cerebral folds than stars in the Milky Way Galaxy.
a)Over 100 billion nerve cells
b) More connections than stars
c)Information travels $\sim 268$ miles/hour

d)Brain is $2 \%$ of body's weight, but uses $20-30 \%$ of your calories

e)Loses an average of 85,000 cells/day

f)Addictions accelerate the brains aging process!! 


\begin{tabular}{|c|c|c|c|c|c|}
\hline $\begin{array}{c}\text { Gabapentin (Fanatrex, } \\
\text { Gabarone, Gralise, } \\
\text { Neurontin) }\end{array}$ & & & & & $\mathrm{X}^{*}$ \\
\hline \multicolumn{6}{|c|}{ Reward Reduction } \\
\hline Disulfiram (Antabuse) & $\mathrm{X}$ & & & & \\
\hline $\begin{array}{c}\text { Naltrexone (ReVia, } \\
\text { Depade, Vivitrol) }\end{array}$ & $\mathrm{X}$ & & & $\mathrm{X}$ & \\
\hline Varenicline (Chantix) & & $\mathrm{X}$ & & & \\
\hline $\begin{array}{l}\text { Modafinil (Provigil, } \\
\text { Alertec, Modavigil) }\end{array}$ & & & $\mathrm{X}^{*}$ & & \\
\hline $\begin{array}{l}\text { Topiramate } \\
\text { (Topamax) }\end{array}$ & $\mathrm{X}^{*}$ & & $\mathrm{X}^{*}$ & & \\
\hline Vaccines & & $\mathrm{X}^{*}$ & $\mathrm{X}^{*}$ & & \\
\hline \multicolumn{6}{|c|}{ Maintenance/ Mediaction- Assisted Therapies } \\
\hline $\begin{array}{l}\text { Nicotine Replacement } \\
\text { Therapy (NRT) }\end{array}$ & & $\mathrm{X}$ & & & \\
\hline Methadone & & & & $\mathrm{X}$ & \\
\hline $\begin{array}{c}\text { Buprenorphine/ } \\
\text { Naloxone (Subutex, } \\
\text { Suboxone) }\end{array}$ & & & & $\mathrm{X}$ & \\
\hline $\begin{array}{c}\text { Oral } \\
\text { Tetrahydrocannabinol } \\
\text { (THC) }\end{array}$ & & & & & $\mathrm{X}^{*}$ \\
\hline
\end{tabular}

Do you know why auto companies require a driver be at least 25 years of age? Because the brain is so complicated and difficult in its total formation it takes 25 years for the brain to complete the billions of synapses connecting each of the major brain sections together. Car rental companies have learned that young incomplete brains make more mistakes in sudden split second decisions. This leads to accidents and or injury to the driver and others.

Columbia calculated that risky substance use- and addictionrelated spending accounted for 10.7 percent of federal, state and local spending, and that for every dollar federal and state governments spent, 95.6 cents went to pay for the consequences of substance use; only 1.9 cents was spent on any type of prevention or treatment. The taxpayer tab for government spending on the consequences of risky substance use and addiction alone totals almost $\$ 1,500$ a year for every person in America. Nearly one-third (32.3 percent) of all hospital inpatient costs are attributable to substance use and addiction.

So what is addiction anyway and how best to treat it. Many theories have been advanced over the decades. One thing we now know is that the basic outline of an inpatient standard 4-6 week stay in a treatment program with an admixture of cognitive testing; individual therapy, group therapy, AA or other self help group, drug testing, family therapy, etc. (with many additions like yoga, equine therapy, gourmet nutritious meals, etc.) about $60 \%$ of patients discharged will relapse in six months or longer. Our outcome success rate has been stuck at that general level since 1980. There has been little real progress with the exception of interventions aimed at the brain. That is because addiction is a complex brain disorder. There is something going on in the brain which is still not completely understood. No small wonder in that the brain again is far more complicated than your heart, lungs, stomach, kidneys, etc.

Some research has led to progress in the treatment in the brain though it still needs further work and evaluation. Here is a sample of more scientifically validated therapies aimed specifically at the brain itself. This new type of treatment is aimed at impacting the brain itself and is referred to as Medication Assisted Treatment (MAT). It's less time intensive, less costly and does interfere with dopamine reception in the brain in different ways. Dopamine is primarily responsible for the euphoric affect one gets when drinking or using drugs. But the brain is still vastly more complicated than taking a pill or injection to cure addiction. It appears to be a first step to assist the patient however.

Next we need to look at some great research on identical twins raised apart. Here the data is pretty clear that such twin pairs have a high probability of becoming addicted to alcohol or drugs regardless of their upbringing or location. In other words, identical twin with a specific combination of 89 genes in their DNA have between a 40\%-75\% probabilities of becoming addicted based on their genes. A simple way to think about this is that a person with normal genes (not the 89 that appear to predispose a person) can say drink a 12 ounce beer with little effect while the person with those 89 genes has a $4 \mathrm{X}$ euphoric effect. So, seeking to better understand what allows those 879 genes to express is an area of future research. Also why do drugs like cocaine have a much higher rate of addiction in identical twins. Likely the power of cocaine on dopamine and a sense of euphoria is a factor that needs to be better understood. 
a.America's approach to addressing risky substance use and providing addiction treatment has evolved outside of the mainstream public health and medical systems. As a result:

i.Most primary providers of intervention and treatment for risky substance use and addiction do not have the requisite training or qualifications to implement the existing range of evidence-based practices and face many organizational and structural barriers to providing services;

ii.Most health professionals do not implement evidencebased addiction care practices;

iii.Performance and outcome measures that should be a routine part of quality assurance in mainstream medicine are limited and rarely implemented in addiction treatment;

iv.The pharmaceutical industry lacks the incentive to develop new and effective pharmaceutical interventions for addiction treatment; and

v.Insurance coverage for evidence-based intervention, treatment and disease management is inadequate.

Because of the vast chasm between the health care system and approaches to preventing risky substance use or treating addiction, medical professionals fail to address risky substance use or addiction or take responsibility for intervention or treatment, risky substance use is addressed primarily in terms of its consequences and addiction treatment providers are not held to the same standards as providers of mainstream medical care. The ultimate goal we must achieve is to deploy Neuroscience and genetics with evidence based interventions if we are to find a more successful outcome for our patients.

b.Neuroscience, over the past 50 years has shown that every thought, sensation, emotion, physical movement is accounted for in terms of brain structures and chemistry.

c.This is not to say that everything is caused by neurons, but nothing happens in human behavior except by the mechanisms of the brain.

d.Behavior, including addiction is related to:

i.Anatomical characteristics of brain regions;

ii.The functions of neurons, including their connectivity into pathways or "circuits"; and,

iii.The neurochemistry that exists between neurons that allows them to interact.

Brain neuroscience explanation of addiction is as follows:

a.The brain consists of millions of "circuits" and pathways.

b.The more a particular pathway is "exercised", the greater the "strength" of that pathway and the more it begins to dominate mental space.

c.However, with neurotransmitters, when an excess is added to the brain system, the brain tries to compensate by getting rid of the excess. So, the more you import, the harder the brain works to get rid of the excess.

d.Over time, the whole distribution of neurotransmitters gets out of kilter and the person can only function when importing the desired neurotransmitters to activate the pleasure parts of the brain.

\section{Summary}

In summary, I have created a nonprofit Foundation (In process for 501C3 status) seeking a cure for addiction. It plans to mimic the City of Hope in Duarte Calif. With a focus on hard research, multidisciplinary teams working together, collaborations with biotech, genetic, medical device and neuroscience organizations as well as fund raising all aimed at our goal of a cure. The name is Addiction Medicine Institute 1024 Bayside Dr. Ste. 459 Newport Beach, Ca. 92660

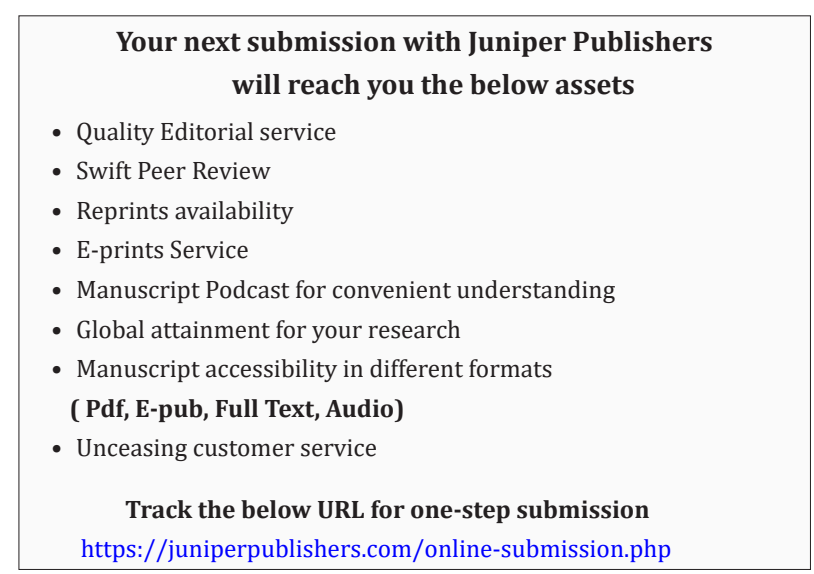

